\title{
捅 New Disease Reports \\ First report of Tomato leaf curl Sinaloa virus infecting tomato crops in Panama
}

\author{
J.A. Herrera-Vásquez ${ }^{1 *}$, D. Ortega ${ }^{2}$, A.B. Romero ${ }^{1}$, S. Davino ${ }^{3,4}$, L.C. Mejía ${ }^{5,6}$, S. Panno ${ }^{4}$ and M. Davino ${ }^{7}$
}

${ }^{1}$ Laboratorio de Protección Vegetal (LPV), Centro de Investigación Agropecuaria Central (CIAC), Instituto de Investigación Agropecuaria de Panamá (IDIAP), Ctra. Panamericana, Los Canelos, Santa María, Estafeta de Divisa, 0619 Herrera, Panama; ${ }^{2}$ Escuela de Biología, Facultad de Ciencias Naturales, Exactas y Tecnología, Universidad de Panamá (UP), Ciudad Universitaria Dr. Octavio Méndez Pereira, Estafeta Universitaria, 3366 Panama 4, Panama; ${ }^{3}$ Department of Agricultural and Forestry Science, University of Palermo, Viale delle Scienze Ed 5, 90128 Palermo, Italy; ${ }^{4}$ Euro-Mediterranean Institute of Science and Technology, Via Emerico Amari 123, 90139 Palermo, Italy; ${ }^{5}$ Centro de Biología Molecular y Celular de Enfermedades, Instituto de Investigaciones Científicas y Servicios de Alta Tecnología (INDICASAT AIP), Edificio 219, Ciudad del Saber, Clayton, PO Box 0843-01103 Panama 5, Panama; ${ }^{6}$ Smithsonian Tropical Research Institute (STRI), Balboa, Ancon, PO Box 0843-03092 Panama, Panama; ${ }^{7}$ Dipartimento DISPA, University of Catania, Via S. Sofia 100, 95123 Catania, Italy

*E-mail: joshervs11@gmail.com

Received: 31 Dec 2014. Published: 21 Jun 2015. Keywords: Solanum lycopersicum, viral plant disease

In April 2011 and September 2012, virus-like symptoms were observed in open field- and greenhouse-grown tomato crops (Solanum lycopersicum) in Chiriquí, the westernmost province of Panama. Samples from symptombearing plants (127 in all) were collected and tested for the presence of begomoviruses by polymerase chain reaction (PCR) assays with sets of degenerated primers designed to amplify parts of the DNA-A and DNA-B components (Rojas et al., 1993; Table 1). Products of the expected sizes, obtained with both DNA-A- and DNA-B-specific primers for 49 samples, suggested infection with New World bipartite begomoviruses. This corresponds to an incidence of $26 \%$ (8 plants) in open field, and $43 \%$ (41 plants) in greenhouse crops. Primers specific for ten tomato-infecting begomoviruses found in Central America (Engel et al., 1998; Nakhla et al., 2005; Table 1) were used to typify the PCR-positive samples.

This analysis revealed Potato yellow mosaic Panama virus (PYMPV) or Tomato leaf curl Sinaloa virus (ToLCSiV) in $44(90 \%)$ or $40(82 \%)$ of the samples, respectively. All contained at least one virus, the majority (i.e. 35) indeed both, with no indication of the other viruses tested. BLAST analysis of two PCR products' sequences of the distinct viruses (GenBank Accession Nos. KP313717 for PYMPV and KP318651 for ToLCSiV, respectively) revealed that KP313717 shared $99 \%$ DNA sequence identity with PYMPV - [Panama:Divisa:Tomato:1996] (PYMPV-[PA:Div:Tom:96], (Y15034) (Engel et al., 1998), and KP318651 $99 \%$ identity with ToLCSiV - [Nicaragua:Santa Lucia] (ToLCSiV-[NI:SL], (AJ608286) (Rojas et al., 2005) and three other ToLCSiV sequences: [Nicaragua:Santa Lucia] (AJ508779), [Nicaragua:Sebaco] (AJ508780) (Rojas et al., 2005), and [Costa Rica:Alajuela] (AF131213); as well as $98 \%$ identity with ToLCSiV-[Nicaragua:Condega] (AJ508778) (Rojas et al., 2005).

Differences in symptom expression were in some cases observed between plants infected with both viruses (Fig. 1A), or with PYMPV (Fig. 1B) or ToLCSiV (Fig. 1C) alone. Begomovirus-free plants (Fig. 1D) also showed virus-like symptoms resembling those induced by other viruses, especially in the Potyviridae and Tobamoviridae (Polston \& Anderson, 1997). Due to the high capacity of recombination between different begomoviruses (Davino et al., 2012), the existence or development of novel recombinant molecules cannot be excluded, which could lead to the emergence of new begomoviruses with different biological properties compared to the ancestral parental viruses in the future. To our knowledge, this is not only the first detection of ToLCSiV in Panama, but also the first report of PYMPV in Panama's western highlands, and the first ever report of PYMPV/ToLCSiV mixed infection. Additional studies on incidence and distribution of these viruses in Panama are in progress.

\section{Acknowledgements}

This study was funded by FONTAGRO and SENACYT (Panama). J.A.H.-V. and L.C.M. were sponsored by the SENACYT SNI program.

\section{References}

Davino S, Miozzi L, Panno S, Rubio L, Davino M, Accotto GP, 2012. Recombination profiles between Tomato yellow leaf curl virus and Tomato yellow leaf curl Sardinia virus in laboratory and field conditions: evolutionary and taxonomic implications. Journal of General Virology $\mathbf{9 3}$, 2712-2717. http://dx.doi.org/10.1099/vir.0.045773-0

Engel M, Fernández O, Jeske H, Frischmuth T, 1998. Molecular characterization of a new whitefly-transmissible bipartite geminivirus infecting tomato in Panama. Journal of General Virology 79, 2313-2317.

Nakhla MK, Sorenson A, Mejía L, Ramírez P, Karkashian JP, Maxwell DP, 2005. Molecular characterization of tomato-infecting begomoviruses in Central America and development of DNA-based detection methods. Acta Horticulturae 695, 277-288.

Polston JE, Anderson PK, 1997. The emergence of whitefly-transmitted geminiviruses in tomato in the Western Hemisphere. Plant Disease 81 1358-1369. http://dx.doi.org/10.1094/PDIS.1997.81.12.1358

Rojas MR, Gilbertson RL, Russell DR, Maxwell DP, 1993. Use of degenerate primers in the polymerase chain reaction to detect whiteflytransmitted geminiviruses. Plant Disease 77, 340-347. http://dx.doi.org/10.1094/PD-77-0340

Rojas A, Kvarnheden A, Marcenaro D, Valkonen JP, 2005. Sequence characterization of Tomato leaf curl Sinaloa virus and Tomato severe leaf curl virus: Phylogeny of New World begomoviruses and detection of recombination. Archives of Virology 150, 1281-1299. http://dx.doi.org/10.1007/s00705-005-0509-x
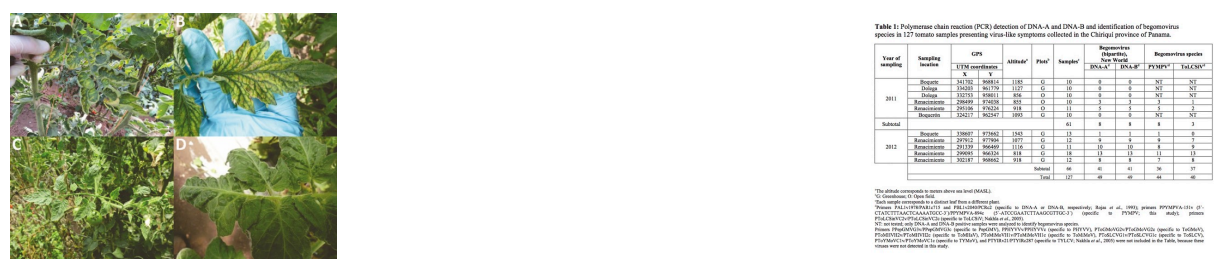

Figure 1

To cite this report: Herrera-Vásquez JA, Ortega D, Romero AB, Davino S, Mejía LC, Panno S, Davino M, 2015. First report of Tomato leaf curl Sinaloa virus infecting tomato crops in Panama. New Disease Reports 31, 30. http://dx.doi.org/10.5197/j.2044-0588.2015.031.030 (c) 2015 The Authors This report was published on-line at www.ndrs.org. uk where high quality versions of the figures can be found. 